\title{
Expanding the Use of Inhaled Vasodilators in Managing Right Ventricular Dysfunction in the Emergency and Critical Care Setting: Should We Broaden Our Vision?
}

Inhaled vasodilators such as nitric oxide, aerosolized epoprostenol, and aerosolized iloprost have been used for decades as selective pulmonary vasodilators to treat both severe hypoxemia and right ventricular dysfunction in diverse conditions associated with pulmonary arterial hypertension, including primary pulmonary hypertension, ${ }^{1}$ hypertension associated with pulmonary fibrosis, ${ }^{2}$ severe $\mathrm{COPD},{ }^{3}$ persistent pulmonary hypertension of the newborn, ${ }^{4}$ and ARDS. ${ }^{5,6}$ Direct pulmonary delivery of vasodilators was a significant advancement in treating pulmonary hypertension because it avoided systemic spillover and systemic arterial hypotension that occurs with intravenous administration..$^{2,7}$

However, because of the short half-life of nitric oxide and epoprostenol, as well as safety concerns, both drugs have typically required endotracheal intubation to achieve safe, continuous administration. This has been a substantial barrier in utilizing these therapies. In contrast, aerosolized iloprost is a long-acting prostacyclin analog with a half-life of 20-30 min (ie, 6.5-10 times longer than the half-life of epoprostenol), which means that its clinical effectiveness can be sustained for up to $2 \mathrm{~h}$ after a single dose. ${ }^{8}$ This feature has made intermittent treatment with inhaled vasodilators more practical, and it increases the potential for its broader clinical application in managing pulmonary hypertension in specific emergency and critical care situations that have not yet been studied adequately.

In this issue of the Journal, the practical impact of inhaled iloprost is highlighted by Enomoto and colleagues, ${ }^{9}$ who studied the efficacy of treating intraoperative pulmonary hypertension with inhaled iloprost versus inhaled epoprostenol in subjects undergoing orthotopic heart transplantation. Both agents effected similar improvements in cardiac index and reductions in mean pulmonary arterial pressures from preoperative baseline measurements. They

\footnotetext{
Mr Kallet is associated with the Asthma and Allergy Prevention Company, McClellan Park, California.

Correspondence: Richard H Kallet MSc RRT FAARC, Associate Editor, Respiratory Care. E-mail: richkallet@gmail.com.
}

DOI: $10.4187 /$ respcare.06979 found no difference between the agents with regard to intraoperative or postoperative mean pulmonary arterial pressure and cardiac index. The only exception was a relatively modest but significantly higher mean arterial pressure in those treated with inhaled iloprost. The most important finding was a significant reduction in the duration of mechanical ventilation.

See the Original Study on Page 743

The authors suggested that decreased mechanical ventilation duration in the iloprost group was attributable to the medication's prolonged action and, therefore, its intermittent dosing requirements. This in turn allowed iloprost to be administered without an endotracheal tube. The implication is that patients who are otherwise ready to resume spontaneous breathing would not require an endotracheal tube to receive this therapy. This is a distinct and important advantage for using iloprost that might have other applications in emergency and critical care settings.

Although the reduction in mechanical ventilation duration did not translate into a reduction in either ICU or hospital length of stay in this small study, it does not necessarily preclude its potential impact on these measures in a larger study and perhaps under different circumstances. For example, inhaled iloprost has been used effectively to treat pulmonary arterial hypertension in subjects with severe COPD, ${ }^{3}$ pulmonary fibrosis, ${ }^{2}$ and severe chronic cardiac failure. ${ }^{10,11}$ It is not implausible, therefore, to consider iloprost as an adjunctive therapy for exacerbations in these patients, with other noninvasive therapies such as highflow nasal oxygen and noninvasive ventilation, either in the emergency department or the ICU. ${ }^{12,13}$ Hypothetically, such bundled therapies hold the possibility of reducing hospital admissions or the need for invasive mechanical ventilation and are worthy of prospective study.

In particular, right ventricular dysfunction from elevated pulmonary vascular resistance is a common finding in patients with ARDS, ${ }^{14}$ related in part to both hypoxemia and disseminated pulmonary intravascular coagulation. ${ }^{15} \mathrm{Be}-$ cause a subset of patients with ARDS now can be managed successfully with either high-flow nasal oxygen ${ }^{16}$ or 


\section{EDITORIALS}

noninvasive ventilation, ${ }^{17}$ there may exist among these patients a role for inhaled iloprost as a temporizing measure. The ability of iloprost to reduce right heart strain and improve oxygenation might further reduce the need for invasive mechanical ventilation in this subset of patients with moderate ARDS.

The study by Enomoto and colleagues ${ }^{9}$ is a welcome addition to the body of literature on the role of inhaled selective pulmonary vasodilators in managing severe cardiopulmonary diseases. Hopefully even the modest contributions of low-level evidence will stimulate interest and expand our vision regarding the possibilities of incorporating inhaled iloprost in managing pulmonary hypertension. Ultimately, this interest must motivate the pursuit of sufficiently powered, prospective randomized trials that will shed light on the actual benefits as well delineate the limitations of noninvasive delivery of inhaled vasodilator therapy.

Richard H Kallet Associate Editor RESPIRATORY CARE

\section{REFERENCES}

1. Pepke-Zaba J, Higenbottam TW, Dinh-Xuan AT, Stone D, Wallwork J. Inhaled nitric oxide as a cause of selective pulmonary vasodilatation in pulmonary hypertension. Lancet 1991;338(8776): 1173-1174.

2. Olschewski H, Ghofrani HA, Walmrath D, Schermuly R, Temmesfeld-Wollbruck B, Grimminger F, et al. Inhaled prostacyclin and iloprost in severe pulmonary hypertension secondary to lung fibrosis. Am J Respir Crit Care Med 1999;160(2):600-607.

3. Wang L, Jin YZ, Zhao QH, Jiang R, Wu WH, Gong SG, et al. Hemodynamic and gas exchange effects of inhaled iloprost in patients with COPD and pulmonary hypertension. Int J Chron Obstruct Pulmon Dis 2017;12:3353-3360.

4. Roberts JD, Polaner DM, Lang P, Zapol WM. Inhaled nitric oxide in persistent pulmonary hypertension of the newborn. Lancet 1992; 340(8823):818-819.
5. Walmrath D, Schneider T, Pilch J, Grimminger F, Seeger W. Aerosolised prostacyclin in adult respiratory distress syndrome. Lancet 1993;342(8877):961-962.

6. Pappert D, Busch T, Gerlach H, Lewandowski K, Radermacher P, Rossaint R. Aerosolized prostacyclin versus inhaled nitric oxide in children with severe acute respiratory distress syndrome. Anesthesiology 1995;82(6):1507-1511.

7. Rossaint R, Slama K, Steudel W, Gerlach H, Pappert D, Veit S, et al. Effects of inhaled nitric oxide on right ventricular function in severe acute respiratory distress syndrome. Intensive Care Med 1995;21(3): 197-203.

8. Olschewski H, Walmrath D, Schermuly R, Ghofrani A, Grimminger F, Seeger W. Aerosolized prostacyclin and iloprost in severe pulmonary hypertension. Ann Intern Med 1996;124(9):820-824.

9. Enomoto TM, Treggiari MM, Merkel MJ. Inhaled iloprost versus epoprostenol in heart transplant recipients. Respir Care 2019;64(7): 743-751.

10. Sablotzki A, Czeslick E, Schubert S, Friedrich I, Muhling J, Dehne MG, et al. Iloprost improves hemodynamics in patients with severe chronic cardiac failure and secondary pulmonary hypertension. Can J Anaesth 2002;49(10):1076-1080.

11. Bautin AE, Iakovlev AS, Tashkhanov DM, Datsenko SV, Marichev AO, Popov MA, et al. [Specifics of inhaled iloprost pharmacodynamics in patients with severe left ventricular systolic dysfunction]. Anesteziol Reanimatol 2015;60(2):4-7.

12. Rochwerg B, Brochard L, Elliott MW, Hess D, Hill NS, Nava S, et al. Official ERS/ATS clinical practice guidelines: noninvasive ventilation for acute respiratory failure. Eur Respir J 2017;50(2): 1602426.

13. Nishimura M. High-flow nasal cannula oxygen therapy in adults: physiological benefits, indication, clinical benefits, and adverse effects. Respir Care 2016;61(4):529-541.

14. Zochios V, Parhar K, Tunnicliffe W, Roscoe A, Gao F. The right ventricle in ARDS. Chest 2017;152(1):181-193.

15. Zapol WM, Snider MT. Pulmonary hypertension in severe acute respiratory failure. N Engl J Med 1977;296(9):476-480.

16. Messika J, Ben Ahmed K, Gaudry S, Miguel-Montanes R, Rafat C, Sztrymf B, et al. Use of high-flow nasal cannula oxygen therapy in subjects with ARDS: a 1-year observational study. Respir Care 2015; 60(2):162-169.

17. Bellani G, Laffey JG, Pham T, Madotto F, Fan E, Brochard L, et al. Noninvasive ventilation of patients with acute respiratory distress syndrome. Insights from the LUNG SAFE Study. Am J Respir Crit Care Med 2017;195(1):67-77. 